\title{
ResearchOnline@JCU
}

This is the author-created version of the following work:

Petray, Theresa, and Pendergrast, Nick (2018) Challenging power and creating alternatives: integrationist, antisystemic and non-hegemonic approaches in Australian social movements. Journal of Sociology, 54 (4) pp. 665-679.

Access to this file is available from:

https://researchonline.jcu.edu.au/51981/

(c) The Author(s) 2018

Please refer to the original source for the final version of this work: 


\section{Challenging Power and Creating Alternatives: Integrationist, Antisystemic and Non-hegemonic approaches in Australian social movements}

Theresa Petray (corresponding author)

College of Arts, Society \& Education

James Cook University

Townsville, QLD 4814

Australia

Theresa.Petray@jcu.edu.au

Nick Pendergrast

Faculty of Arts \& Education

Deakin University

Melbourne, VIC 3151

Australia

\section{nicholas.pendergrast@deakin.edu.au}

Acknowledgments: Some of the research this paper builds on research conducted at Curtin University during Nick Pendergrast's PhD candidature. Some of the research was funded by James Cook University's Special Studies Program. The authors would like to thank Scott Fitzgerald, Jan SinclairJones, and anonymous reviewers for their feedback, as well as the activists who have helped us shape our argument in this paper.

Theresa Petray is a Senior Lecturer in Sociology \& Anthropology at James Cook University in Townsville. She researches Aboriginal activism and self-determination. Nick Pendergrast is a Lecturer \& Tutor in Sociology, Criminology \& Anthropology at University of Melbourne and Deakin University. He researches animal advocacy and social movement theory. 


\title{
Challenging Power and Creating Alternatives: Integrationist, Antisystemic and Non-hegemonic approaches in Australian social movements
}

\author{
Social movements are often discussed as either reformist or revolutionary, or more \\ often, as containing aspects of each of these approaches. However, whether a \\ movement seeks integration into the existing system or it seeks to overthrow that \\ system and replace it, both approaches are hegemonic in nature. That is, they focus on \\ totalising power structures. In this paper, we explore another aspect of social \\ movements: non-hegemonic approaches are those which prefigure alternatives at the \\ local level. Non-hegemonic approaches are not oriented to power structures like states. \\ Instead of actively resisting power, they bypass it or in some ways, ignore it, as they \\ create new ways of being. This approach may be limited in scope, and is unlikely to \\ challenge the existence of inequalities at broad scales, but they can point to real \\ examples of alternatives to existing power structures.
}

Keywords: utopias; Indigenous; animal advocacy; reform; radical; non-hegemonic

\section{Introduction}

Social movements are often categorised as either integrationist or antisystemic. In some cases this is a profoundly important distinction based on different goals, but is often about the strategy to achieve those goals. Integrationism is seen as more achievable; making small steps towards change is better than nothing. Antisystemic activism seeks to replace the existing system in which inequality is embedded. The concept initially united two distinct types of movements: social movements and national movements (Wallerstein 2002). Since the 1970s, however, there have been changes to how movements organise and operate, as well as to movement scholarship. We now study a broad array of movements in addition to labour and nationalist struggles. Antisystemic activism is still often differentiated from integrationist approaches, or those which work for progressive, incremental change within the current system (Wallerstein 2003:653,658). Both antisystemic and integrationist concepts still refer to approaches with a state-orientation though. Integrationist activism seeks incorporation into 
the state and antisystemic approaches seek to occupy the state apparatus themselves (Wallerstein 2002:30), or at least directly challenge power. A third category has emerged: activism which is non-hegemonic is not directed at power structures (Day 2005). This category is based on Gramsci's (1999:690) understanding of hegemony as a 'historical bloc', a totalitarian, unified and all-absorbing system of ideologies. That is, Gramsci's use of the term hegemony to refer to groups seeking political, social and cultural influence over others (Gramsci 1999:20). Non-hegemonic activists do not seek totalising change; they create alternatives alongside the existing structure instead of engaging with that structure. For clarity in this paper, we will refer to antisystemic (or integrationist, or non-hegemonic) activism or approaches, rather than movements, because we recognise that multiple approaches are often part of a larger social movement with shared goals.

In this paper, we synthesise several theoretical discussions of social movements with two empirical examples, in order to gain a more complete picture of these three categories within social movements: integrationist, antisystemic, and non-hegemonic. We focus on two examples from Australia: Indigenous activism and animal advocacy. These movements are seemingly quite different; Indigenous activism typically makes claims to the state while animal advocates seek lifestyle changes that will lead to systemic change. However, both movements contain elements that are integrationist and antisystemic, as well as state-centric and non-hegemonic. We argue that activism which is oriented towards power structures, whether seeking inclusion or a radical change, is no longer the only, nor even the most effective, way to bring about long-lasting and meaningful social change. Instead, nonhegemonic activism is increasingly popular as an experiment in creating alternatives to power structures. In doing so, social movements 'reflect utopian aspirations for transformed conditions for human flourishing, yet they also seek ways to embody those aspirations in real institutions’ (Wright 2011:42). These non-hegemonic approaches may still operate 
incrementally, celebrating small wins that contribute to the larger goal, but they measure success differently; they are incremental but not integrationist. Our examples show the complexities of social movements which rarely, if ever, fit neatly into our scholarly typologies. This paper will first discuss theoretical approaches to integrationist, antisystemic, and non-hegemonic change and explore the differences between them. We will then discuss examples of Australian social movements, focusing especially on animal advocacy and Indigenous rights because of the diverse ways these movements embody the different approaches to social change. In so doing, we suggest the addition of this third category to the traditional dichotomy between radical and liberal.

\section{Integrationist, Antisystemic and Non-hegemonic Social Change}

Integrationist social change seeks small, incremental changes to the existing structure. This is also known as a reformist or liberal approach. According to Wallerstein (2014:158-9), liberalism arose in response to reactionary conservatism, with liberals arguing that some change was inevitable but would be best undertaken in a slow and limited manner. Liberal ideologies did not embrace change, but saw it as inevitable and sought to temper its effects. The concept of liberal or integrationist social change today refers to change sought through existing power structures (Maddison \& Scalmer 2006). Integrationism does not seek to replace or uproot those structures; instead, this approach accepts existing power structures and seeks inclusion within those. This approach to social change is often criticised by more radical activists because of the slow pace of change and the risk of co-optation. Minor concessions to liberal demands seemingly 'persuade the more radical forces that change [is] in fact taking place’' (Wallerstein 2014:159). For this reason, some movements experience schism over strategy, with more radical factions arguing that integrationist wins will detract from the overall goal, or even questioning the idea that integrationist wins are positive steps 
at all.

Antisystemic approaches, on the other hand, are those which are known as radical or revolutionary. They struggle against existing power structures, rather than seeking integration within them. Wallerstein (2014:160) discusses several divisions within this radical ideology: between social movements and national movements, and more importantly for our argument here, between activism opposed to states or other power structures and activism which sought to obtain state power in order to achieve social change. Day (2001:33, following Deleuze \& Guattari 1986) likens antisystemic action to 'war-machines' which seek to destroy old structures of power and build something new in its place. While the process of co-optation for radical approaches is different than for reformist ones, the risk is still present. The revolution which does not succeed in uprooting state power 'must pass into the service of the state or destroy itself (Day 2001:33, original emphasis). In other words, radical activism eventually either dies out or becomes part of the very structures it once opposed. Another challenge for antisystemic approaches is the process of bureaucratisation - as social movements grow, they often form bureaucratic structures and their activities become influenced by their need for resources (Jurik 2008; McCarthy \& Zald 1997; 2001; Soule \& King 2008).

Social movements are made up of a diverse range of individuals and organisations with different objectives and tactics (Soule \& King 2008:1568). Maeckelberg (2011:1) describes the alterglobalization movement, which advocates for alternatives to neoliberal globalisation, as composed of 'multiple threads', an apt description for all large social movements. As a result, movements can generally not be categorised as entirely anti-systemic or integrationist, but tend to have elements of each. This is partially because, as Wallerstein (2014:171) points out, movements must address constituents’ urgent needs. This might mean ‘short-term compromises', which are essential but 'in no way transform the system’. Radical activists struggle with the decision to make these compromises, hoping that the comfort 
which results does not lead to complacency. Large social movements contain both integrationist and antisystemic elements.

Both antisystemic and integrationist approaches to social change face internal and external pressures which may dilute a movement’s success. Integrationist approaches risk placating constituents and the general public, as power structures make minor concessions and thus reduce opposition to their power. Antisystemic approaches must weigh up stability and longevity with the risks of bureaucratisation and becoming part of the power structures they oppose. These challenges are the result of the orientation towards hegemonic power structures in these approaches: whether seeking inclusion within these structures or demanding change from it, social movements recognise their power.

Though there are countless examples throughout history of non-state oriented social change, the phenomenon has picked up steam recently, and has also gained increasing attention from scholars. One reason for the increasing popularity of this movement strategy is that, in a globalising, neoliberal world, movements realised that 'state power was more limited than they had thought' (Wallerstein 2002:32). Moreover, they were disenchanted by earlier antisystemic activism which did successfully gain state power, but then focused more on retaining that power than enacting the intended social reforms (Wallerstein 2014:161; Schaefer \& Weyher 2013:3). Similar critiques have been made of overly-bureaucratised social movements even when they do not gain state power. NGOs like Greenpeace, for example, are seen by some as a 'multinational pseudo-capitalist pseudo-state' (Day 2004:729). In both cases, the perceived failure is because these movements focus too much on hegemony.

Instead, some movements are doing what Wallerstein (2002:39) suggests: imagining an alternative society, and beginning experiments in those alternatives. Day’s (2004; 2005) concept of 'non-hegemonic movements' is an apt description for these approaches because 
they do not seek totalising power. Instead of seeking hegemony, they refuse the idea of universalisation altogether, introducing a politics 'which take us beyond both reform and revolution’ (Day 2004:730, original emphasis). The experimentation with alternatives is referred to as prefiguration: 'the attempted construction of alternative or utopian social relations in the present, either parallel with, or in the course of, adversarial social movement protest' (Yates 2015:1). Conceptually, prefiguration is slippery and is applied to a wide range of examples (Maeckelberg 2011; Yates 2015). Here, we understand prefiguration as a practice of social change, something that social movements do. Rather than entering the debate about how best to define prefiguration, we find the concept of non-hegemonic approaches more useful in distinguishing a social movement's orientation to power structures.

Non-hegemonic activism, rather than actively protesting against power structures, creates non-totalising alternatives allowing for small-scale experiments in a different kind of society. Important to these 'newest' approaches is 'a commitment to the notion that the means of radical social change must be consistent with its ends' (Day 2004:723). This is similar to what anarchist activists and theorists call 'direct action', which creates spaces of 'autonomy' while at the same time critiquing and challenging the power of the state (Graeber 2002:68). Direct action is often driven by anarchist values. Those engaged in it are often confronted with symbols of authority including the police, the government and the law (Drew 2014:84,88,94). These discussions of direct action, though, still imply a strong focus on protest and agency exercised as resistance to power (Ortner 2006). Day (2004:733) refers to this as a 'politics of demand': 'actions oriented to ameliorating the practices of states, corporations and everyday life, through either influencing or using state power'. A serious risk of this approach is that movement participants experience burn out through constantly trying to manifest their resistance (Arrighi, Hopkins \& Wallerstein 1986:185). In contrast, 
some non-hegemonic activism focuses more on agency as the enactment of projects (Ortner 2006), a 'politics of the act' (Day 2004), the building and creating of alternatives; direct resistance is not the point, even though these alternatives might challenge power structures merely by existing. Non-hegemonic activists practicing a politics of the act 'set out to block, resist and render redundant both corporate and state power in local, national and transnational contexts’ (Day 2005:45).

Approaches which focus more on the creation of alternatives than on changes to the existing system are arguably freer. However, they may fail, or be short-lived. They are 'necessarily partial in their scope, and necessarily, to some extent, inside the field of constituted power’ (Coté, Day \& de Peuter 2007:329, original emphasis). One potential problem with this approach is the implicit lack of outreach (Deslandes \& King 2006). Because the goal of this activism is not to achieve hegemony, these approaches do not always intend to convince others of their tactics and can become closed to outsiders. There is potential that they will alienate potential members because they are not actively trying to change the system, but it is more likely that outsiders will simply be unaware of their existence.

Day (2005) does not see this limited scope as a drawback, but rather one of the defining features of these approaches. While not directly challenging power structures, nonhegemonic approaches may serve as practical examples of anti-capitalist utopias. Because they do not actively engage with power structures, these projects do not draw the attention of those power structures. Day (2004:735 following Hardt \& Negri 2000) discusses the risk of co-optation for movements that attempt to disrupt structures of capitalism. When the system is presented with a new challenge, it adjusts and finds new ways of accommodating and incorporating that resistance. It recognises the challenge, and responds to it, thus bringing that resistance from outside the system to inside. This discussion of anti-capitalist resistance can 
be extended to discussions of other power structures. Non-hegemonic approaches are less likely to be co-opted when they pair tactics of 'disengagement and reconstruction' (Day 2004:739). They are willing to co-exist with the structures they oppose, but by disengaging and providing meaningful alternatives, strive to eventually render such structures redundant (Graeber 2004:7). Graeber summarises this strategy of 'engaged withdrawal':

The theory of exodus proposes that the most effective way of opposing capitalism and the liberal state is not through direct confrontation but by means of what Paolo Virno has called "engaged withdrawal," mass defection by those wishing to create new forms of community. One need only glance at the historical record to confirm that most successful forms of popular resistance have taken precisely this form. They have not involved challenging power head on (this usually leads to being slaughtered, or if not, turning into some- often even uglier — variant of the very thing one first challenged) but from one or another strategy of slipping away from its grasp, from flight, desertion, the founding of new communities (Graeber 2004:61).

In what remains of this paper, we will look at examples of Australian social movements, highlighting how these three elements - integrationist, antisystemic, and nonhegemonic - intersect and diverge.

\section{Indigenous Rights Movement}

One of the major contemporary political campaigns with regards to Australian Aboriginal and Torres Strait Islander peoples is the Constitutional recognition campaign. For several years this was led by Recognise, a non-governmental organisation which is funded by the government and has bipartisan support but is not without opposition. In 2017 the focus has shifted from Recognise, which we discuss below. The key rationale for Constitutional recognition of Aboriginal and Torres Strait Islander peoples is that they are not currently acknowledged in the Australian Constitution at all. Prior to 1967, Indigenous peoples were mentioned in the Constitution twice. Both used the term 'aboriginal', incorrectly 
encompassing both Aboriginal and Torres Strait Islander peoples in a singular term. Section 51, which clarifies the division of powers between the Federal and State governments, gave the Federal government 'power to make laws for the peace, order, and good government of the Commonwealth with respect to the people of any race, other than the aboriginal race [sic] in any State, for whom it is deemed necessary to make special laws'. Section 127 excluded Aboriginal and Torres Strait Islander people from population counts in determining electoral boundaries and funding: 'In reckoning the numbers of the people of the Commonwealth, or of a State or other part of the Commonwealth, aboriginal natives [sic] shall not be counted'. In the 1967 Referendum, over 90\% of Australians voted to remove 'other than the aboriginal race' from Section 51, and to entirely remove Section 127 from the Australian Constitution. This was seen as a 'watershed moment' (Watson 2015:28), a chance to begin correcting past injustices towards Aboriginal and Torres Strait Islander peoples (Wright 2014). Following those changes, the Australian Constitution no longer has any mention whatsoever of Indigenous peoples, and activists see another opportunity for a watershed moment with their campaign.

Supporters of Constitutional recognition use a number of points to support their campaign. Most abhor the exclusion of Aboriginal and Torres Strait Islander peoples, the omission and erasure of more than 40,000 years of culture prior to colonisation (Castan 2015; Williams 2015; Morris 2013). The Australian Medical Association (2015) and Australian Psychological Society (2013) suggest that recognition leads to respect and value, and will positively affect Aboriginal and Torres Strait Islander health outcomes, including social and emotional wellbeing. For some, it is about changing the national identity, that 'all Australians could walk taller' if Aboriginal and Torres Strait Islander peoples are recognised (Brennan 2015:18; Gooda 2014). Likewise, some proponents of Constitutional recognition highlight the benefit it would have for Australia's reputation in the international arena (Wright 2014). 
Despite support from both major political parties, though, Constitutional recognition does have opponents. In this paper we are interested in the opponents, primarily Aboriginal and/or Torres Strait Islander themselves, who oppose recognition because they do not want inclusion in the Constitution. The arguments put forward by these opponents illustrate the tensions between integrationism and antisystemic activism, and are increasingly incorporating debates between state-oriented activism and non-hegemonic approaches. Aboriginal activist and writer Celeste Liddle is an outspoken opponent of Constitutional recognition, and her position reflects the antisystemic approach to the topic. She does not want to be 'assimilated into a document that was written by a coloniser regime' (Liddle 2013). This represents a rejection of integrationism. Inherent in any Constitutional amendment is the belief that states should be given the authority to allow recognition. But from the antisystemic approach, 'the state’s assumed position ... is itself what is contested' by Indigenous peoples (Coulthard 2014:100).

In Petray’s fieldwork with Aboriginal activists in North Queensland, many conversations about Constitutional recognition refer to it as a distraction. These are the people who are not 'satisfied with a modest, largely symbolic change’ (Brennan 2015:20). This position challenges the basis that Aboriginal and Torres Strait Islander peoples can even be considered part of 'Australia' without first recognising their sovereignty as peoples here before colonisation. These activists argue that sovereignty was never ceded by Aboriginal and Torres Strait Islander peoples. This is the position taken, for example, by the Australian Greens Party; they argue for a treaty or treaties with Indigenous nations alongside Constitutional recognition (Henderson 2016). An open meeting of Aboriginal peoples in the state of Victoria unanimously rejected Constitutional recognition, instead demanding treaties and an Elders Council (Reconciliation Victoria 2016). The wording of the motions indicates the underlying reasons for this refusal: 'We as Sovereign People reject Constitutional 
Recognition’ (Reconciliation Victoria 2016). This motion sends a clear message that the offer of recognition is rejected because these Aboriginal people do not want to be integrated within the state structure. This stance is not the same as the nationalist movements which sought statehood for oppressed peoples (Wallerstein 2014:160). While there are some Aboriginal nations publicly declaring independence from Australia (Liddle 2013), the majority of indigenous nations do not seek statehood (Anaya 2009:15). Nonetheless, we argue that these activists represent an antisystemic approach because they do not seek integration and resist the state structure that is trying to incorporate them. In fact, they are opposed to this symbolic integration because they fear it will detract from what they feel is the more important goal of a treaty.

In 2017, the Referendum Council hosted a series of Regional Dialogues, followed by the First Nations National Constitutional Convention at Uluru in May. Aboriginal and Torres Strait Islander delegates discussed and debated Constitutional recognition, and several other options for change. What clearly emerged from this process was a widespread lack of interest in symbolic recognition of First Nations people in the Australian Constitution (Referendum Council, 2017). The Uluru Statement from the Heart (2017) positions Aboriginal and Torres Strait Islander peoples as 'the first sovereign Nations' and seeks both a constitutionally recognised First Nations Voice and a Makarrata Commission to undertake a 'process of agreement-making between governments and First Nations'. This is effectively a middle ground between the two positions discussed above - it rejects symbolic recognition but still pursues 'a constitutionally entrenched institution which enables Aboriginal and Torres Strait Islander peoples to be formally consulted on legislation and policy affecting their communities' (McKay 2017). But at the same time, it foregrounds the importance of Makarrata, or treaties. 
In contrast to the Constitution which was written 'against the backdrop of racism' (Williams 2015:215), a treaty would necessarily be negotiated between the state and Indigenous peoples (Liddle 2013). However, even the notion of treaties is state-centric. Signing a treaty places authority firmly in the hands of the state. As history shows us, treaties with Native nations around the world have been ignored at the whim of states (Coulthard 2014). There is a necessary pragmatism that activists adopt when speaking about treaties. We live in a system where states have considerable power, and a treaty is a meaningful way for Native nations to access some of that power. We are not critical of the activists who adopt this approach, and while there are some opponents to the Uluru Statement (Blanco 2017), it has largely been embraced by Aboriginal and Torres Strait Islander people across Australia (McKay 2017). But we are also interested in other ways of doing activism which focus more on the politics of the act than the politics of demand (Day 2004).

As Liddle (2014) acknowledges, ‘Certainly Constitutional recognition doesn’t mean much to people taking action to emancipate themselves from Australian laws'. Rather than becoming entangled in a debate over Constitutional recognition versus a treaty, some Aboriginal and Torres Strait Islander peoples are simply creating spaces where they can exercise self-determination. This non-hegemonic approach is not necessarily opposed to either the integrationist push for Constitutional recognition, or the antisystemic push for treaties. Instead, they are building self-determination from the ground up (though many of the people engaged in this work may also be active in antisystemic treaty campaigns or integrationist recognition campaigns). They do so despite the lack of legal recognition of their rights to self-determination (Cornell 2015:18). In Indigenous studies, this is referred to as the 'nation-building approach’ (Cornell 2015; Jorgensen 2007), and in the Australian political context it is more obviously non-hegemonic than in places where the right to self-government may be 'granted' by the state. This approach to Indigenous rights is not about demanding a 
change from the system; it does not seek recognition or integration within states. It does not take a universalising stance, recognising the boundaries of an Aboriginal nation and the importance of cultural uniqueness. It would not make sense for an Aboriginal nation to push their self-determination model on anyone else, either other Aboriginal nations or the Australian state. Aboriginal nations do not seek to expand their territory, recruit new members, or dominate others.

While the nation-building approach is non-hegemonic and focuses on the creation of alternatives rather than changing existing structures, it does still work incrementally. In Petray’s nation-building research project with the Gugu Badhun nation, the community has identified a need to make small steps in order to achieve the ultimate goal of selfdetermination. This remains distinct, though, from integrationist change because the incremental change is still a politics of the act (Day 2004). Gugu Badhun, and nations like it, seek to assert self-determination over an increasing range of domains. Cornell (2015:19), writing on the Ngarrindjeri nation in South Australia, describes their process of nationbuilding as 'having clawed back a significant measure of decision-making power in several policy domains'. Every successful assertion of self-determination is a win in the nonhegemonic struggle for Indigenous rights. Instead of demanding sovereignty be recognised by the Australian government, these nations are exercising self-determination without permission.

The Indigenous movement in Australia is vast, and comprises far more issues than those discussed here. But the examples of Constitutional recognition, sovereignty, and selfdetermination highlight the coexistence of integrationist and antisystemic, and state-centric and non-hegemonic approaches to the same issue. It is important for the cause to have multiple approaches and in this example the antisystemic approach can use successful nonhegemonic examples to bolster their cause. These prefigurative experiments in self- 
determination strengthen the case for treaties negotiated with self-determining Aboriginal nations.

\section{The Animal Advocacy Movement}

Like the Indigenous rights movement, the animal advocacy movement (AAM) is made up of a diverse range of individuals and organisations with different objectives and tactics (Soule \& King 2008:1568). As a result, it cannot be simply categorised as entirely integrationist, antisystemic or non-hegemonic but is comprised of elements of each. As a result, approaches adopted by animal advocates reflect a wide range within this spectrum.

An important issue for the Australian AAM in recent years is the live export of Australian animals for slaughter in other countries. Integrationist approaches within the AAM include campaigns to replace live animal export with chilled flesh from animals slaughtered in Australia (Pendergrast 2015:101, 106). This campaign has broad support in Australia, with 69 per cent of Australians believing 'that the live export trade should be ended' (WSPA 2012). Campaigning to end live animal export is clear example of integrationist advocacy, as it works within the dominant animal welfare perspective, which has widespread support amongst Australians. Animal welfare is an integrationist approach to understanding and addressing humans’ relationship with non-human animals (Munro 2012:170; O'Sullivan 2006:3). The animal welfare approach accepts and promotes the idea of non-human animals being used for human ends in most cases, as long as certain safeguards are put in place to offer some protection for these animals (Bourke 2009:132-133; Francione 1996:1). It also accepts the current property status of non-human animals and speciesism (discrimination based on species) but attempts to place constraints on how this property may be treated and limit the damage caused by speciesism, through animal welfare regulations (Munro 2012:170; White 2009:97). 
Animal welfare can be classified as the 'default' position in Western society, or 'the status quo position' (White 2009:97). It is widely viewed as a 'moderate and respectable' position (Francione 1996:163) and is accepted by 'almost everyone' (Francione 1996:1). This includes a large majority of citizens in countries like Australia (Sankoff \& White 2009: 9) and even those who directly use and kill other animals for purposes such as food or experimentation (Francione 1996:1; Garner 2006:161). In a survey of 2000 Australians, ninety-three per cent of people either agreed or strongly agreed with the statement that it is: 'Quite acceptable to eat meat so long as animals are reared and killed humanely’ (Franklin 2007:22). This idea of humane slaughter is central to the animal welfare perspective and to the campaign against live export (Pendergrast 2015:101, 110, 113). Campaigners against live export work within dominant speciesist attitudes. Animal welfare campaigners accept existing inequalities but seek small, incremental improvements in the treatment of non-human animals.

Rather than accepting these existing inequalities through integrationist activism, direct action activists in the AAM struggle against existing power structures. This includes companies who use non-human animals, as well as existing laws, with direct action activists sometimes breaking laws on behalf of non-human animals. Such activism is the clearest example of antisystemic activism in the AAM. In 2003, animal advocate Ralph Hahnheuser intervened in the Australian live export industry by placing processed pig flesh into the feed of sheep bound for the Middle East. The consumption of this pig flesh meant that these sheep no longer met Halal requirements and were thus unsuitable for export to predominantly Muslim countries (Khoo 2009:58-60). This act shows the intersections between different approaches within the AAM. In this case, the attempt to directly disrupt the system of animal use was predicated on the exploitation of another animal. The direct use of pig flesh by this activist underpins the animal welfare focus of the Ban Live Export campaign, which is not 
focused on rejecting animal slaughter, but rather challenging where the slaughter is taking place (Pendergrast 2015:109-110).

The most famous example of antisystemic activism in the AAM is the Animal Liberation Front, a direct action network which engages in sabotage in the name of nonhuman animals (Best \& Nocella 2004; Glasser 2011). Two of the most common forms of direct action in Australia are against the duck shooting and kangaroo cull. This has involved sabotaging these activities, including some cases of property damage (Animal Liberation Front 2014; Drew 2014; McIlroy 2014).

The animal liberation perspective, unlike animal welfare, demands the abolition, rather than reform, of animal exploitation and slaughter. It also differs from integrationist approaches because it works outside institutions such as the state (Best 2009:25). Munro (2012:174) argues that these activists 'pose more of a threat to the financial and physical well-being of its targets' than other approaches to animal advocacy. Animal liberation uses disruption to work towards the overthrow of a system that is built on the exploitation of animals. It is not generally directed at the state as the key powerholder, but still directly confronts structures of power, particularly industries that use non-human animals.

In contrast to antisystemic approaches, a small proportion of the AAM who are opposed not just to ‘inhumane’ slaughter overseas, but to all forms of animal exploitation, enact their opposition by creating alternatives. Vegan advocacy is an alternative response to widespread outrage at footage of animals from Australia being slaughtered overseas. Unlike integrationist Ban Live Export campaigners who seek legal reforms in the treatment of animals, Australian animal advocacy organisations such as the Vegan Society of New South Wales and Animal Liberation Victoria call on people concerned about the issue to become vegans (ALV 2011; Vegan Society NSW 2011). Campaigners from these groups reject the widely accepted notion of 'humane slaughter' that is prominent in the messaging of those 
calling for live export to be banned. Vegan advocacy is an example of non-hegemonic activism, as it is a matter of withdrawing from the existing system, rather than challenging it 'head on' in the case of direct action, or accepting it in the case of animal welfare. The idea of imagining an alternative society and beginning experiments in those alternatives (Wallerstein 2002:39) is central to veganism, both as an individual practice, and as an advocacy tactic within the AAM. Veganism is about both imagining a society without the exploitation and slaughter of non-human animals, as well as putting this into practice right now through individual dietary and other choices. Francione (2010:62) explains that 'veganism is a profound moral and political commitment to [the] abolition [of animal exploitation] on the individual level and extends not only to matters of food but also to the wearing or using of animal products'. Veganism is a rejection of the idea of non-human animals as merely resources for human use and a recognition of their intrinsic moral value (Francione 2010:62). Veganism also makes the more philosophical statement of being an example of the idea that many people can live without using animals as property or products. Such a notion reflects the acknowledgement of the importance of connecting means and ends (Day 2004:723).

Veganism highlights, however, the intersections between non-hegemonic activism and other, state-centric approaches. Vegan activists attended rallies against live export with banners and flyers promoting this alternative response, although unlike those promoting the more 'respectable' message of 'humane slaughter', they were neglected in mainstream media coverage of the issue (Author2). Further, Francione (2010) emphasises the importance of promoting veganism in incrementally moving towards the goal of the abolition of animal exploitation. Francione (2010:62) argues that the increasing adoption of veganism leads towards the legal personhood of non-human animals (the alternative to being viewed as property) and the abolition of their exploitation. This is both through immediately reducing 
the demand for animal products and building a long-term movement that can lead to meaningful legal prohibitions on animal use in the future (Francione 2010:64-65,71).

Veganism also highlights one of the key limitations of non-hegemonic activism: its limited reach. As we discuss above, veganism is about withdrawing from industries that use non-human animals, rather than directly challenging them. As a result, it may pose less threat to these industries than direct action activism (Munro 2012:174). Indeed, in some ways, it poses less threat than even integrationist animal welfare reforms. While veganism means that these industries lose a small portion of their market through a (currently) very small proportion of people withdrawing their support for these industries (The Vegetarian/Vegan Society of Queensland 2010:3-4), the industries are able to carry on as they otherwise would. In this way, vegan advocates co-exist with animal industries, whereas welfare changes force these industries to change their practices in some way and direct action activists physically disrupt their operations. However, merely by existing, vegans challenge these industries by rendering them redundant on an individual level, and imaging a society where they are no longer needed or desired. Vegan advocacy alongside integrationist and antisystemic activism makes the AAM stronger, as with this added dimension, the movement as a whole strives to not only reform animal industries and directly confront them, but also offers alternatives in a new and different society.

\section{Conclusion}

The traditional dichotomy of integrationist/antisystemic, liberal/radical, reformist/revolutionary, is not adequate to understand the 'politics of demand', or creating change. A third category, non-hegemonic, allows sociologists to better understand social movement activities which are not directed at power-holders. Further, this diversity is useful within social movements; both integrationist and antisystemic activists can refer to non- 
hegemonic alternatives as a meaningful example of what change might look like. We build on work from Day and Wallerstein in an attempt to better understand what is possible. In this endeavour, we follow Wright's (2013:168) development of 'a social science of the possible, not just of the actual'. Non-hegemonic activism is as valuable to this social science as it is to social movements themselves.

In this paper we have demonstrated how the addition of the non-hegemonic category to social movement typology helps us to better understand the diverse approaches of social movements. We focused on two examples: Indigenous rights, specifically the debate over Constitutional recognition, treaties, and the enactment of self-determination at the local level; and animal advocacy, specifically the Ban Live Export campaign, animal liberation, and enacting change through veganism. A thorough analysis of other movements was beyond the scope of this paper. However, the internal debates that occur within the two social movements that were discussed in this paper are typical of social movements generally, whether they are state-centric as is the Indigenous rights movement, or more lifestyle-based like the AAM. We encourage further research exploring these debates and particularly the presence of non-hegemonic advocacy in other social movements and countries. 


\section{References}

ALV. (2011) 'Ban Live Export'. Accessed from

$<$ http://www.alv.org.au/storyarchive/0843end-live-export/end-live-export.php>, 31 July 2011.

Anaya, S. J. (2009) International Human Rights and Indigenous Peoples. New York: Wolters Kluwer.

Animal Liberation Front (2014) ‘Actions Reported to Bite Back’. Accessed from $<$ http://www.animalliberationfront.com/ALFront/Actions-AustraliaNZ/BitebackReports2013.htm>, 3 May 2016.

Arrighi, G., T.K. Hopkins and I. Wallerstein (1986) 'Dilemmas of Antisystemic Movements', Social Research 53(1):185-206.

Australian Medical Association (2015) ‘AMA Takes Stand Against Racism, Backs Indigenous Constitutional Recognition', Australian Medicine. Accessed from $<$ https://ama.com.au/ausmed/ama-takes-stand-against-racism-backs-indigenousconstitutional-recognition>, 14 April 2016.

Australian Psychological Society (2013) Submission to the Joint Select Committee on Constitutional Recognition of Aboriginal and Torres Strait Islander Peoples on the Inquiry into Aboriginal and Torres Strait Islander Recognition Bill 2012.

Best, S. (2009) 'The Rise of Critical Animal Studies: Putting Theory into Action and Animal Liberation into Higher Education’, Journal for Critical Animal Studies 7(1):9-52.

Best, S., and A.J. Nocella (2004) 'Behind the Mask: Uncovering the Animal Liberation Front', pp.9-64 in S. Best \& A. J. Nocella (eds), Terrorists or Freedom Fighters?: Reflections on the Liberation of Animals. New York: Lantern Press.

Blanco, C. (2017) ''We won't sell out our mob': Delegates walk out of Constitutional recognition forum in protest', NITV News, 25 May.

Bourke, D. (2009) 'The Use and Misuse of 'Rights Talk' by the Animal Rights Movement', pp.128-150 in P. J. Sankoff \& S. White (eds), Animal Law in Australasia: A New Dialogue. Sydney, Australia: Federation Press.

Brennan, F. (2015) 'Constitutional Change that will Improve Indigenous Quality of Life’, Eureka Street 25(12):18-20.

Castan, M. (2015) 'Constitutional Recognition, Self-Determination and an Indigenous Representative Body', Indigenous Law Bulletin 8(19):15-18. 
Cornell, S. (2015) 'Processes of Native Nationhood: The Indigenous Politics of SelfGovernment', International Indigenous Policy Journal 6(4):1-27.

Coté, M., R. Day and G. de Peuter (2007) 'Utopian Pedagogy: Creating Radical Alternatives in the Neoliberal Age', Review of Education, Pedagogy, and Cultural Studies 29(4):317-336.

Day, R. (2001) 'Ethics, Affinity and the Coming Communities’, Philosophy \& Social Criticism 27(1):21-38.

Day, R.J.F. (2004) 'From Hegemony to Affinity', Cultural Studies 18(5):716-748.

Day, R.J.F. (2005) Gramsci is Dead: Anarchist Currents in the Newest Social Movements. Toronto: Pluto Press.

Deslandes, A. and D. King (2006) 'Autonomous Activism and the Global Justice Movements: Aesthetic Reflexivity in Practice’, Journal of Sociology 42(3):310-327.

Drew, L. (2014) 'Embodied Learning Processes in Activism', The Canadian Journal for the Study of Adult Education 27(1):83-101.

Francione, G. (1996) Rain Without Thunder: The Ideology of the Animal Rights Movement. Philadelphia: Temple University Press.

Francione, G. (2010) 'The Abolition of Animal Exploitation', pp.1-102 in G. Francione and R. Garner (eds), The Animal Rights Debate: Abolition Or Regulation? New York: Columbia University Press.

Franklin, A. (2007) 'Human-Nonhuman Animal Relationships in Australia: An Overview of Results from the First National Survey and Follow-up Case Studies 2000-2004', Society and Animals 15:7-27.

Garner, R.R. (2006) ‘Animal Welfare: A Political Defense’, Journal of Animal Law and Ethics 1:161-174.

Glasser, C.L. (2011) Moderates and Radicals Under Repression: The U.S. Animal Rights Movement, 1990-2010. (Doctor of Philosophy), University of California, Irvine.

Gooda, M. (2014) 'Don’t Let the Sun Set on a Noble Act', The Australian, 22 August.

Graeber, D. (2002) 'The New Anarchists’, New Left Review 13:61-73.

Graeber, D. (2004) Fragments of an Anarchist Anthropology. Chicago: Prickly Paradigm Press.

Gramsci, A. (1999) Selections from the Prison Notebooks. Q. Hoare and G.N. Smith (trans and eds). London: ElecBook. 
Henderson, A. (2016) 'Greens Urge Malcolm Turnbull to Consider Treaty with Indigenous People alongside Constitutional Recognition Push’, ABC News, 9 February. Jorgensen, M. (Ed) (2007) Rebuilding Native Nations: Strategies for Governance and Development. Tucson: University of Arizona Press.

Jurik, N.C. (2008) 'The Promises and Realities of U.S. Microenterprise Development', pp.5773 in M.L. DeVault (ed.), People at Work: Life, Power, and Social Inclusion in the New Economy. New York: New York University Press.

Khoo, O. (2009) 'A New Call to Arms or A New Coat of Arms? The Animal Rights and Environmentalism Debate in Australia', Journal of Animal Law 5:49-70.

Liddle, C. (2013) 'Indigenous Recognition Debate Deserves Better than this Political Jostling', The Guardian, 11 July.

Liddle, C. (2014) 'Indigenous Recognition: We Have More Diverse Views Than the Official Campaign', The Guardian, 22 September.

Maeckelberg, M. (2011) 'Doing is Believing: Prefiguration as Strategic Practice in the Alterglobalization Movement', Social Movement Studies 10(1): 1-20.

McCarthy, J.D. and M.N. Zald (1997) 'Resource Mobilization and Social Movements: A Partial Theory’, pp.149-171 in S.M. Buechler and J.F. Kurt Cylke (eds), Social Movements: Perspectives and Issues. California: Mayfield Publishing Company. McCarthy, J.D. and M.N. Zald (2001) 'The Enduring Vitality of the Resource Mobilization Theory of Social Movements’, pp.533-566 in J. H. Turner (ed.), Handbook of Sociological Theory. New York: Springer.

McIlroy, T. (2014) ‘Kangaroo Cull Protester Vandalism Price Tag: \$50,000-Plus’, The Canberra Times, 21 September.

McKay, D. (2017) ‘Uluru Statement: A Quick Guide’, Parliamentary Library Research Paper Series, 19 June.

Morris, S. (2013) 'Constitutional Reform for Indigenous Recognition and Equality Before the Law’, Legaldate 25(4):2-4.

Munro, L. (2012) 'The Animal Rights Movement in Theory and Practice: A Review of the Sociological Literature', Sociology Compass 6(2):166-181.

O'Sullivan, S. (2006) 'Conflict and Coherence within the Australian Animal Protection Movement', Australasian Political Studies Association conference, University of Newcastle, 25-27 September 2006. 
Pendergrast, N. (2015). Live Animal Export, Humane Slaughter and Media Hegemony. Animal Studies Journal, 4(1), 99-125.

Reconciliation Victoria (2016) Aboriginal Community Open Meeting with Victorian Aboriginal Affairs Minister Natalie Hutchins, ZINC Federation Square. February 3, 2016. Meeting Summary accessed from <http://www.reconciliationvic.org.au/userdata/Constitutional_Recognition/RecVic_ConRec_statement_Feb_2016_FINAL.pdf> , 14 April 2016.

Referendum Council (2017) 'Aboriginal and Torres Strait Islanders Peoples from Across Australia Make Historic Statement’, Media Release, 26 May. Accessed from $<$ https://www.referendumcouncil.org.au/event/uluru-statement-from-the-heart>, 26 June 2017.

Sankoff, P.J. (2009) 'The Welfare Paradigm: Making the World a Better Place for Animals?', pp.7-34 in P.J. Sankoff and S. White (eds), Animal Law in Australasia: A New Dialogue. Sydney: Federation Press.

Sankoff, P. and S. White (2009) 'Introduction', pp.1-6 in P. Sankoff and S. White (eds), Animal Law in Australasia: A New Dialogue. Sydney: Federation Press.

Schaefer, R.K. and L.F. Weyher (2013) 'World-system and social movements', pp.1-4 in D.A. Snow, D. della Porta, B. Klandermans and D. McAdam (eds), The WileyBlackwell Encyclopedia of Social and Political Movements. Malden, MA: Wiley. Soule, S.A. and B.G. King (2008) 'Competition and Resource Partitioning in Three Social Movement Industries', American Journal of Sociology 113(6):1568-1610.

Uluru Statement from the Heart (2017) Statement on the First Nations National Constitutional Convention. Accessed from $<$ https://www.referendumcouncil.org.au/event/uluru-statement-from-the-heart>, 26 June 2017.

The Vegetarian/Vegan Society of Queensland (2010) A Pound of Flesh. Accessed from <http://www.scribd.com/doc/26880337/APF-VVSQ>, 5 December 2011.

Vegan Society NSW (2011) Live Animal Export. Accessed from <http://www.vegansocietynsw.com/vs/html/liveexport.html>, 31 July 2011.

Wallerstein, I. (2002) 'New Revolts Against the System’, New Left Review 18:29-39.

Wallerstein, I. (2003) ‘Citizens All? Citizens Some! The Making of the Citizen’, Comparative Studies in Society and History 45(4):650-679. 
Wallerstein, I. (2014) ‘Antisystemic Movements, Yesterday and Today’, Journal of WorldSystems Research 20(2):158-172.

Watson, N. (2015) 'Book Review: Everything You Need to Know About the Referendum to Recognise Indigenous Australians’, Indigenous Law Bulletin 8(19):28-9.

White, S. (2009) 'Exploring Different Philosophical Approaches to Animal Protection in Law’, pp.79-107 in P.J. Sankoff and S.W. White (eds), Animal law in Australasia: A New Dialogue. Sydney: Federation Press.

Williams, G. (2015) 'Why It’s Time to Recognise Indigenous Peoples in the Constitution', Australasian Psychiatry 23(3):214-217.

Wright, B. (2014) 'Indigenous Recognition: Completing Our Constitution', LSJ: Law Society of NSW Journal 1(4):72-3.

Wright, E.O. (2013) 'Real Utopias’, Politics \& Society 41(2):167-9.

Wright, E.O. (2011) 'Real Utopias’, Contexts 10(2):36-42.

WSPA (2012) 'Almost 7 in 10 Australians Against Live Animal Export', WSPA. Accessed from

<http://www.wspa.org.au/latestnews/2012/Almost_7_in_10_Australians_against_live _animal_export.aspx>, 1 June 2013.

Yates, L. (2015) 'Rethinking Prefiguration: Alternatives, Micropolitics and Goals in Social Movements', Social Movement Studies 14(1):1-21. 